\title{
The morphological characteristics of the passive flexor mechanism of birds with different digit layout
}

\author{
Tajana Trbojević Vukičević1*, Stanko Galić2, Danijela Horvatek Tomić3, \\ and Snježana Kužir ${ }^{1}$ \\ ${ }^{\prime}$ Department of Anatomy, Histology and Embryology, Faculty of Veterinary Medicine, University of Zagreb, \\ Zagreb, Croatia \\ ${ }_{2}^{2}$ Prophyl Ltd., Mohacs, Hungary \\ ${ }^{3}$ Department of Poultry Diseases with Clinic, Faculty of Veterinary Medicine, University of Zagreb, Zagreb, \\ Croatia
}

\section{TRBOJEVIĆ VUKIČEVIĆ, T., S. GALIĆ, D. HORVATEK TOMIĆ, S. KUŽIR: The morphological characteristics of the passive flexor mechanism of birds with different digit layout. Vet. arhiv 88, 125-138, 2018.}

\section{ABSTRACT}

Birds possess a mechanism which allows passive flexion of the digits of the hind limbs which consists of two components: "automatic digital flexor mechanism" (ADFM) and "digital tendon-locking mechanism" (DTLM). The aim of this paper was to establish the existence and specificities of those components in examples of birds with anisodactyl (domestic chickens) and zygodactyl (parrots) digit layout using standard anatomical dissection and histological methods. Spatial distribution of the parrots' muscles with a central role in DTLM (M. flexor digitorum longus and $\mathrm{m}$. flexor hallucis longus) was the same as the chickens'. The plantar position of the fourth digit, which makes the difference between the anisodactyl and the zygodactyl digit layouts, did not cause changes in the position and function of this flexor muscles. The domestic chickens' tendon sheath ridges, as well as the tendon tubercles of the flexor muscles were less developed while the parrots' tubercles and ridges were clearly defined and the differences in their morphology were visible. There were no chondrogenic elements or they were barely noticeable in the parrots' tendons. A potential cause of these distinctions could be the difference in the load which the tendons endure due to the different biomechanical composition. The parrots primarily inhabit trees where they move agilely around by grasping the branches. The Galliformes have a much larger body mass which is a consequence of their life on the ground, so the flexor muscle tendons suffer a greater load than the parrots and the cartilage tissue embedded in the tendon itself could act to distribute the weight of the body borne by the foot and the tendon.

Key words: anisodactyles; zygodactyles; automatic digital flexor mechanism; digital tendon-locking mechanism, birds

\footnotetext{
*Corresponding author:
}

Assoc. Prof. Tajana Trbojević Vukičević, PhD, DVM, Department of Anatomy, Histology and Embryology, Faculty of Veterinary Medicine, University of Zagreb, Heinzelova 55, 10000 Zagreb, Croatia, Phone: +385 12390241 Fax: +385 12441 390; E-mail: tajana@vef.hr 
T. Trbojević Vukičević et al.: Morphology of the passive flexor mechanism in birds

\section{Introduction}

Bird systematics are constantly subject to changes and additions, but the approximate number of 10000 species classifies them as the most diverse group within modern vertebrates (SIBLEY et al., 1988; BRUSATTE et al., 2015; CLEMENTS et al., 2017). When considering the differences between bird clades, one of the most important characteristics is the variable morphology of the foot, where the number of digits and their spatial distribution are described as seven different types: anisodactyl (songbirds and most other perching birds), zygodactyl (most parrots, woodpeckers, owls, cuckoos), heterodactyl (trogons), syndactyl (kingfishers, hornbills), pamprodactyl (swifts), and didactyl (ostrich Struthio camelus) and tridactyl (emu Dromaius novaehollandiae) types, which arose as a secondary classification based on whether they have two or three digit (PROCTOR and LYNCH, 1993; FEDUCCIA, 1996). The foot connectivity is also one of the important morphological characteristics, by which birds are classified into five types: palmate (ducks, geese, swans, gulls, terns and other aquatic birds), totipalmate (cormorants, pelicans, gannets, boobies), semipalmate (all grouse, some domestic breeds of chicken, sandpipers, plovers), lobate (grebes) and raptorial (kites, hawks, eagles and falcons) (PROCTOR and LYNCH, 1993; O’MALLEY, 2005). Most birds possess a mechanism which allowed passive flexion of the digits of the hind limbs while perching, but it also functions in other activities, such as foot-propelled swimming, scratching, wading, prey - grasping, clinging, hanging, and tree climbing and has some other purposes, mostly for grasping objects or food (QUINN and BAUMEL, 1990; GALTON and SHEPHERD, 2012). The function of birds' flexor apparatus has been interpreted as a collection of structural elements which temporarily combine the fixed tendon sheath with a mobile tendon in order to flex the digits (QUINN and BAUMEL, 1990).

Despite the fact that examination of the aforementioned mechanism began already with BORELLI's pioneer work in 1685 , recent scientific considerations have not satisfyingly explained their role (GALTON and SHEPHERD, 2012). Two important components were detected and described in previous investigations: the "automatic digital flexor mechanism" (ADFM) and the "digital tendon-locking mechanism" (DTLM) (QUINN and BAUMEL, 1983; QUINN and BAUMEL, 1990; GALTON and SHEPHERD, 2012). When compared to mammal tendons, bird tendons are significantly longer connective tissue formations which transmit mechanic force, often passing through several joints (KAISER, 2007).

Related to the ADFM, the flexion of the intertarsal joint is a necessary movement during flexion of the knee, due to the fact that the active muscles are not long enough and these joints could not flex separately. The flexion of the intertarsal joint is a consequence of the synergistic action of the $\mathrm{m}$. iliofibularis, $\mathrm{m}$. tibialis cranialis, $\mathrm{m}$. flexor digitorum longus (MFDL) and $\mathrm{m}$. flexor hallucis longus (MFHL), when the knee joint is in a flexed 
position. The movement of the tendons of these muscles during flexion of the intertarsal joint, above the tibial cartilage and hypotarsus, is passive, also causing tension in the tendons of the most important digit flexors (MFDL and MFHL), and consequently the flexion of the digits. This mechanism occurs automatically without any muscular work (WATSON, 1869; SCHAFFER, 1903; SCHRANKE, 1930; BOCK, 1965; GALTON and SHEPHERD, 2012).

QUINN and BAUMEL (1990) described the DTLM as areas of tubercles located on the ventral surface of the tendons (area tuberculata tendinis) and the ridges located on the inside surface of the surrounding tendon sheath (plicae vaginae tendinis). The most important muscles included in this mechanism are MFDL and MFHL, which are attached to each other by a fibroelastic band (vinculum tendinum flexorum) in some birds (VAN DEN BERGE and ZWEERS, 1993). According to GOSLOW (1972), these muscles cannot be separated in a functional sense because their tendons are connected in the distal segments. Due to the effects of the birds' weight or other mechanical forces when performing some movements, the tendon tubercles and ridges of the according sheaths slot into each other and consequentially maintain their position or increase its durability (GOSLOW, 1972). According to QUINN and BAUMEL (1990), the structural adaptations of the tendons and sheath modifications involving the MFDL are variable and some birds possess only distal patches, and others possess proximal and distal patches. Proximal patches may extend into other tendons ( $\mathrm{mm}$. perforans and perforatus), as in Corvus brachyrhynchos and Ardea herodias, while Cygnus olor, Anas platyrhynchus and Numenius tahitiensis lack the DTLM on the MFHL.

The aim of this paper is to establish the existence and specificities of the passive flexor mechanism (both ADFM and DTLM) in representatives of birds with anisodactyl (domestic chicken) and zygodactyl (parrots) digit layouts using standard macro and micromorphological methods, in order to establish differences that may be related to locomotor habits.

\section{Materials and methods}

Animals. Various bird species were used, depending on the different digit layout (Table 1). For the anisodactyl feet type group, altogether 20 samples of the distal hind limb parts of domestic chickens (Gallus gallus domesticus, Galliformes) were collected. The second group of samples belonged to birds with zygodactyl feet type, including all parrots (Psittaciformes) (Table 1). The chicken samples were taken during lecture activities at the Department of Anatomy, Histology and Embryology, and parrot samples were taken from deceased birds admitted to the Department of Poultry Diseases with Clinic, both part of the Faculty of Veterinary Medicine, University of Zagreb. This research was approved by a decision of the Ethics Committee of the Faculty of Veterinary Medicine, University of Zagreb. 
T. Trbojević Vukičević et al.: Morphology of the passive flexor mechanism in birds

Table 1. List of the specimens according to the digit layout

\begin{tabular}{|c|c|c|c|c|}
\hline \multicolumn{2}{|l|}{ Species } & \multirow{2}{*}{$\begin{array}{c}\text { Sex } \\
\mathrm{F} \text { and } \mathrm{M}\end{array}$} & \multirow{2}{*}{$\begin{array}{l}\text { Age } \\
\text { adult }\end{array}$} & \multirow{2}{*}{$\begin{array}{c}\mathrm{N}^{\mathrm{o}} \text { of samples } \\
10 \mathrm{left} \\
10 \mathrm{right}\end{array}$} \\
\hline $\begin{array}{l}\text { Anisodactyl } \\
\text { type }\end{array}$ & $\begin{array}{l}\text { Domestic chicken } \\
\text { (Gallus gallus domesticus) }\end{array}$ & & & \\
\hline \multirow{8}{*}{$\begin{array}{l}\text { Zygodactyl } \\
\text { type }\end{array}$} & $\begin{array}{l}\text { Turquoise-fronted amazon } \\
\text { (Amazona aestiva) }\end{array}$ & $\mathrm{F}$ & 2 years & $\begin{array}{l}1 \text { left } \\
1 \text { right }\end{array}$ \\
\hline & $\begin{array}{l}\text { Salmon-crested cockatoo } \\
\text { (Cacatua moluccensis) }\end{array}$ & M & 10 months & $\begin{array}{l}1 \text { left } \\
1 \text { right }\end{array}$ \\
\hline & $\begin{array}{l}\text { Rose-ringed parakeet } \\
\text { (Psittacula krameri) }\end{array}$ & $\mathrm{F}$ & 4 years & $\begin{array}{l}1 \text { left } \\
1 \text { right }\end{array}$ \\
\hline & $\begin{array}{l}\text { African grey parrot } \\
\text { (Psittacus erythacus) }\end{array}$ & M & $1-3$ years & $\begin{array}{l}1 \text { left } \\
1 \text { right }\end{array}$ \\
\hline & $\begin{array}{l}\text { Eastern rosella } \\
\text { (Platycercus eximius) }\end{array}$ & M & 8 years & $\begin{array}{l}1 \text { left } \\
1 \text { right }\end{array}$ \\
\hline & $\begin{array}{l}\text { Maroon-bellied parakeet } \\
\text { (Pyrrhura frontalis) }\end{array}$ & - & 2 months & 4 right \\
\hline & $\begin{array}{l}\text { Yellow-crowned amazon } \\
\text { (Amazona ochrocephala) }\end{array}$ & - & adult & $\begin{array}{l}1 \text { left } \\
1 \text { right }\end{array}$ \\
\hline & $\begin{array}{l}\text { cockatiel } \\
\text { (Nymphicus hollandicus) }\end{array}$ & - & adult & $\begin{array}{l}1 \text { left } \\
1 \text { right }\end{array}$ \\
\hline
\end{tabular}

Macromorphological approach. The birds' hind limbs were separated by disarticulation of the hip joint and the samples were fixed and preserved in $10 \%$ buffered formalin. Skin, with the feathers and/or keratin scales, was removed in the area of tibiotarsus and tarsometatarsus. A detailed section of the $\mathrm{m}$. flexor digitorum longus and $\mathrm{m}$. flexor hallucis longus was performed. It was followed by incision of the plantar part of the flexor tendons in order to open the tendon sheath to visualize its inner part using a 5x magnifier. After photographing, samples of MFDL tendons and parts of tendon sheaths were taken for histological research (see below). Hind limbs were finally boiled in a solution of detergent in order to eliminate soft tissues and analyze the osteological elements (BAUMEL and WITMER, 1993). Osteological and histological analyses were carried out on representatives of the genus Amazona (Turquoise-fronted amazon) and Psittacus (African grey parrot), as well as on domestic chicken hind limbs.

Micromorphological approach. Samples of the MFDL tendon and its sheath, situated plantar to the subterminal joint III digit, embedded in paraffin and cut to $7 \mu \mathrm{m}$ thick cuts, were submitted for micromorphological analysis. Histological cuts were stained in order to determine collagen and elastic formations, using standard methods: hematoxylin-eosin (H\&E), Mallory for the collagen, Pincus method and Verhoeff - Van Gieson (SHEEHAN and HRAPCHAK, 1980). Histological samples were observed by optical microscope BX41 (Olympus). 


\section{Results}

Macro and micromorphological analysis of the chicken leg. The hypotarsus consisted of several prominent bone grooves (sulcus hypotarsi) (Fig. 1A), and one completely closed up bone tunnel (canal hypotarsi) on the caudal side (Fig. 1B). Tibial cartilage was connected to the plantar surface of the hypotarsus and it also contained grooves on its dorsal surface. Hypotarsal bone and tibial cartilage grooves were connected and produced tunnels through which the digit flexor tendons passed.
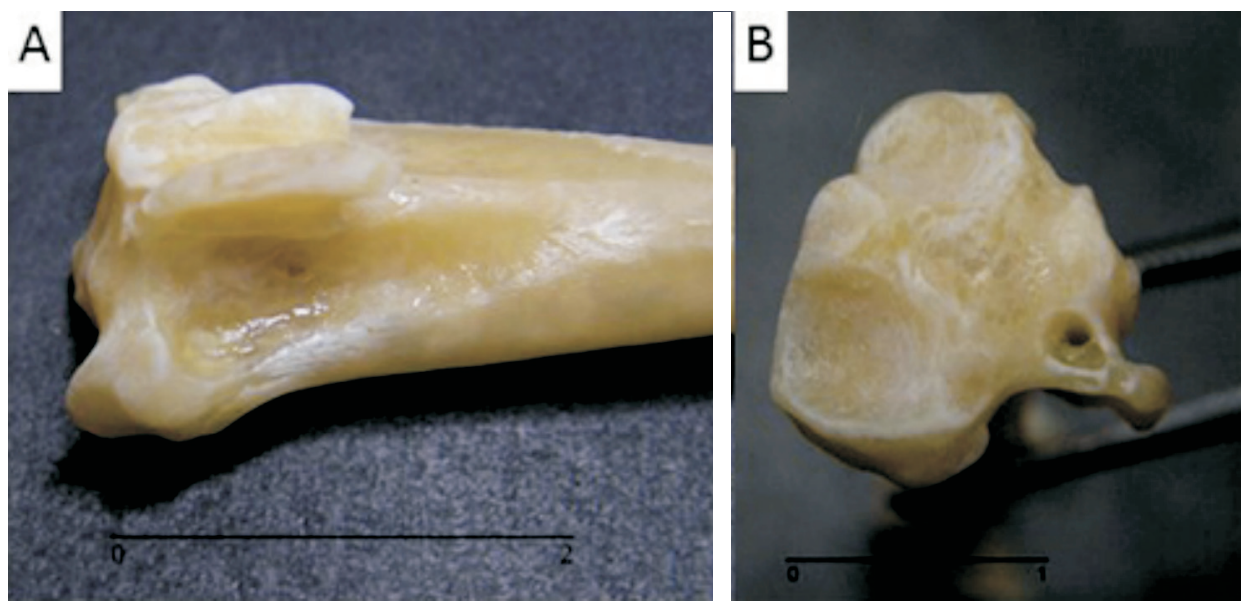

Fig. 1. Domestic chicken hypotarsus; A - norma medio-plantaris; B - norma proximalis

The MFDL origin was caudally on the fibula and proximal epiphysis of the tibiotarsus, and it was attached via the tibial cartilage and hypotarsus tunnel and inserted at the plantar side on the flexor tubercle (tuberculum flexorium) of the second, third and fourth digits' ungual phalanx. Its function was flexion of the $2^{\text {nd }}-4^{\text {th }}$ digits as well as the extension of the intertarsal joint. The MFHL originated with two heads distally on the caudal surface of the femur, and it was also attached via the tibial cartilage and the hypotarsus tunnel, and inserted on the plantar side on the flexor tubercle (tuberculum flexorium) of the $1^{\text {st }}$ digit's ungual phalanx. Its function was flexion of the $1^{\text {st }}$ digit, as well as extension of the intertarsal joint.

After longitudinal incision of the MFDL's tendon sheath, the magnifier showed ridges on the inner side which participated in DTLM and were most prominent in the subterminal phalange area.

The structure of the MFDL tendon of digit III was clearly visible on the histological slides: densely formed connective tissue, built of collagen fibers and fibrocytes. In the area 
of the epitendon more densely placed oval fibrocytes nucleus were visible, positioned in two or three rows. In the area just before the DTLM components, a synovial bilayer was visible. A rich layer of loose connective tissue and a significantly thinner layer of compact dermis between the tendon sheath and epidermis were also noticed.

In the area of the tendon sheath, the epitendon was shaped by mild bulges-tubercles (Fig. 2) that fit into the indentations of the tendon sheath ridges (Fig. 3). Clearly visible clusters of chondrocytes or empty lacuna on parts of the tendon, typical for fibrous cartilage were also present.

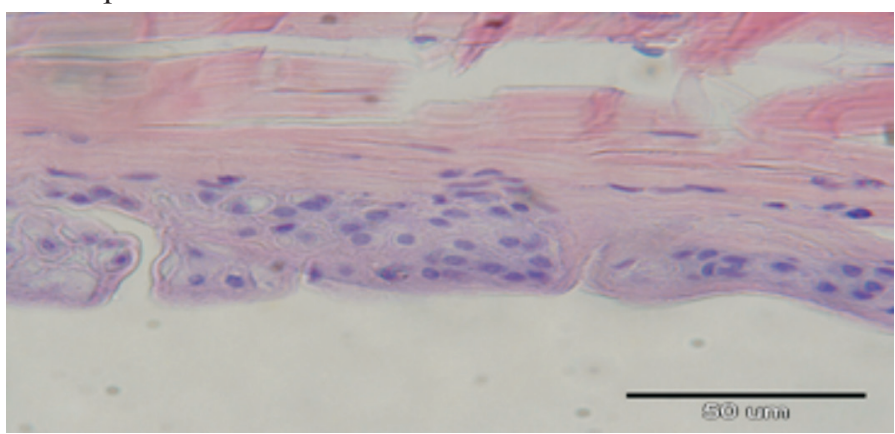

Fig. 2. Tubercles micromorphology at the MFDL tendon surface at domestic chicken, H\&E

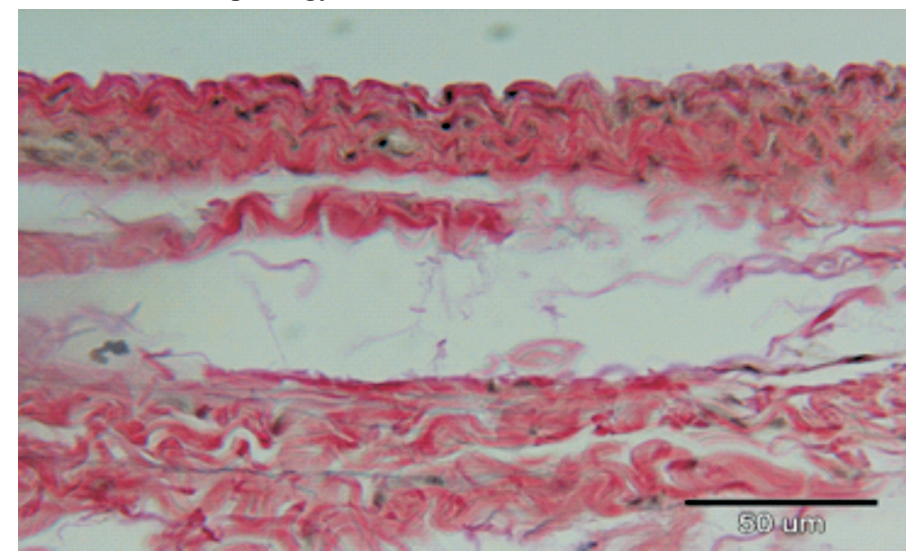

Fig. 3. Ridges micromorphology at MFDL tendon sheet inner surface at domestic chicken, Verhoeff - Van Gieson

Macro and micromorphological analysis of the parrot's leg. Grooves (sulcus hypotarsi) on the caudal surface of the hypotarsus, together with the tibial cartilage grooves, made numerous tunnels through which digit flexor tendons passed (Fig. 4A; example of the African grey parrot). In the inner part of the hypotarsus of the parrot representatives two 
completely separate bone tunnels (canales hypotarsi) were noticed through which the digit bender tendons passed (Fig. 4B; example of the African grey parrot). The MFDL originates caudally on the fibula and proximal epiphysis of the tibiotarsus, attached over the tibial cartilage and hypotarsus tunnel, and inserted on the plantar side onto the flexor tubercle (tuberculum flexorium) of the second, third and fourth digits' ungual phalanx. Its function was flexion of the $2^{\text {nd }}-4^{\text {th }}$ digits, as well as the extension of the intertarsal joint. The MHFL originated with two heads distally on the caudal surface of the femur and was also attached over the tibial cartilage and hypotarsus tunnel and inserted into the plantar side on the flexor tubercle (tuberculum flexorium) of the first digit's ungual phalanx. Its function was flexion of the first digit, as well as the extension of the intertarsal joint. There was no difference between the left and right hind limbs.
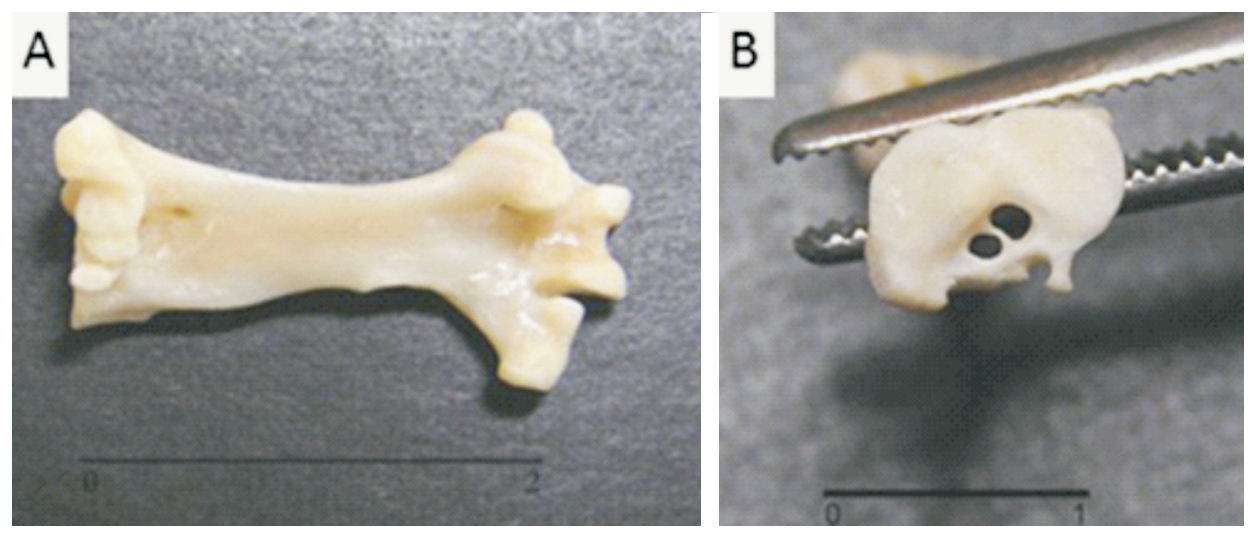

Fig. 4. African grey parrot hypotarsus; A - norma plantaris; B - norma proximalis

After the incision of the tendon sheath on the plantar side of the MFDL tendon of digit III, there were ridges visible on the inner surface of the sheath and they were most prominent in the subterminal phalanx area.

The histological slides of the MFDL tendon of digit III of the parrots showed: densely formed connective tissue, built of collagen fibers and fibrocytes. Clearly limited, differently shaped tubercles appeared in the area of the epitendon.

In the Turquoise-fronted Amazon, the shapes were uneven (Fig. 5A), some were narrow rectangular and some were twice as wide. In the African grey parrot, they were a uniform rectangular shape (Fig. 5B), more narrow at the base and wider at the apical part. The nucleus of the cells in the African grey parrots were mainly at the base, while in the Turquoise-fronted Amazon, they were on the entire surface of the tubercles. The base of the tubercles lay on the evenly arranged collagen fibers of the tendon, between which the fibrocytes nucleus were visible. No elastic fibers were found. 
T. Trbojević Vukičević et al.: Morphology of the passive flexor mechanism in birds

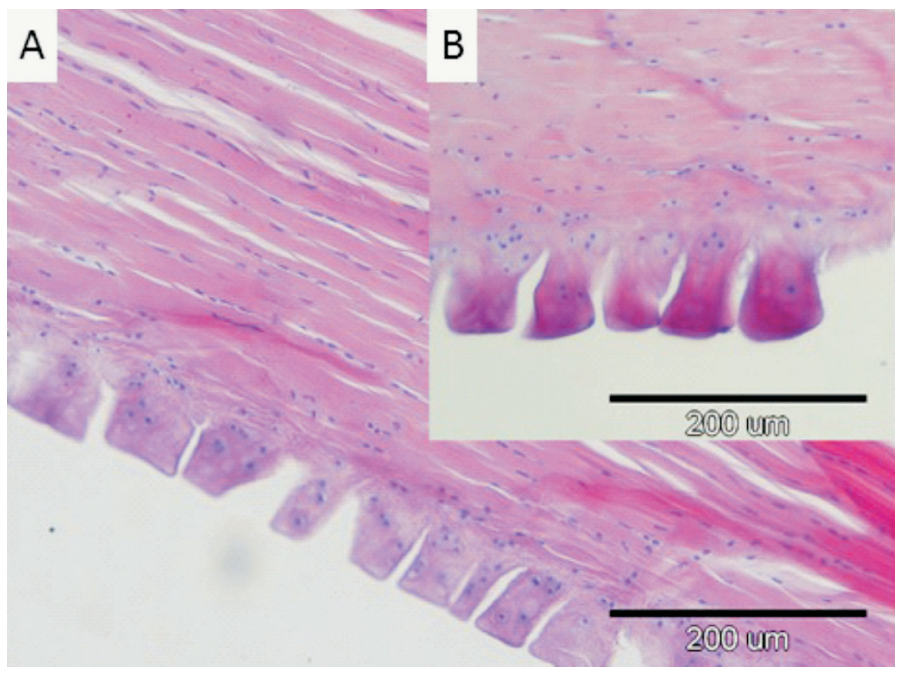

Fig. 5. Comparative view of the tubercles at MFDL tendon surface; A - Turquoise-front $d$ amazon; B - African grey parrot

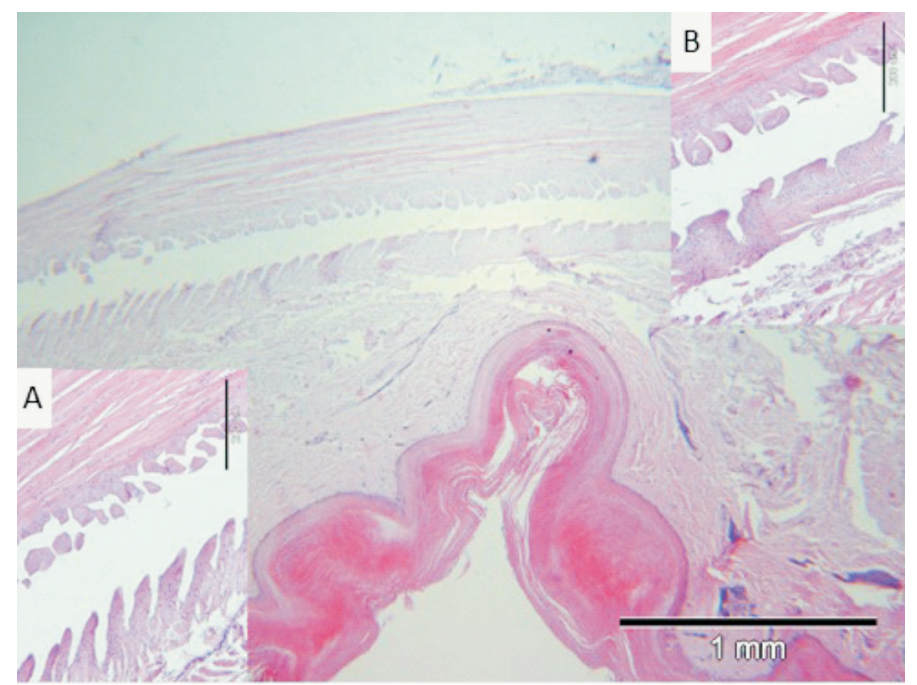

Fig. 6. Cross section of MFDL tendon and tendon sheet of the African gray parrot; tendon tubercles and sheet ridges; A- abaxial; B - axial (H\&E) 
The inner side of the tendon sheath had shaped ridges which were clearly separated. Every ridge was built out of irregularly positioned collagen fibers, between which numerous fibrocytes nucleus were visible. The ridges were also differently shaped and sized: e.g. in the African grey parrot, they were thin and shaped like leaves on the abaxial part (Fig. 6A) and much wider and rectangular in the axial part (Fig. 6 B). In the Turquoise-fronted Amazon, the ridge base was narrow and leaf-like, shorter at the abaxial part (Fig. 7A) and much longer at the axial part (Fig. 7B).
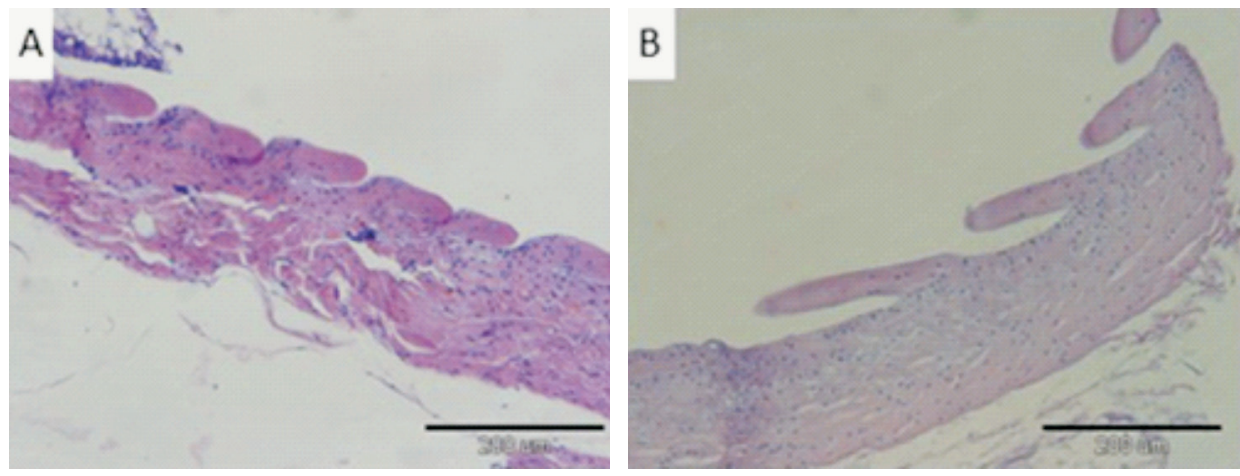

Fig. 7. Ridges at MFDL tendon sheet of the Turquoise-fronted amazon third digit; A -abaxial part of the sheet; B - axial part of the sheet (H\&E)

\section{Discussion}

Macromorphological observations. In the domestic chicken, the MFDL originated on the plantar surface of the tibiotarsus, the tendon part passed through the hypotarsus canal and was divided to the tendons which inserted on the flexor tubercles (tuberculum flexorioum) of the second, third and fourth digits' ungual phalanges. The MFHL originated with two heads on the thigh bone: the dorsal head on the caudolateral and medial head on the intercondylar part of the femur, and its tendon was inserted into the flexor tubercle (tuberculum flexorioum) of the first digit's claw (BAUMEL and WITMER, 1993; GOSLOW, 1972; HUMMEL, 2000; KÖNIG et al., 2009; McLELLAND, 1990; NICKEL et al., 1977; AVDIĆ et al., 2014).

There have been previous osteological (e.g. MAYR, 2008, 2010) and mycological (e.g. BERMAN, 1984; CARRIL et al., 2014) studies regarding the hind limbs of Psittaciformes, but in this investigation all the components of the passive flexor mechanism in several species of parrots were examined for the first time. In the inner part of the investigated parrots' hypotarsus, there were two completely separated bone tunnels (canales hypotarsi), which was the morphological difference between their bone formation compared to chickens. 
The spatial distribution of the muscles, with a central role in DTLM (MFDL and MFHL), was the same as the chicken's. It is important to point out that the plantar position of the fourth digit did not cause changes in the position, beginning, ending and function of this flexor muscle, which made the difference between the anisodactyl and zygodactyl digit layout (GALIĆ, 2013).

Ridges on the inner part of the MFDL's tendon sheath are present in the area of the subterminal phalanges both in Gallus and parrots. The high level of similarity in the anatomical organization of the elements counted, as well as the finding of the DTML components described indicated the conclusion that both the observed groups, representatives of birds with different digit layouts, possessed a digital flexor mechanism which was structurally and functionally similar.

Some of the biological features of the observed species influence the flexor mechanism. Psittaciformes, as representatives of zygodactyls, are considered to be an arboreal species according to their ecological niches. In addition, they show many ethological qualities which imply frequent and sophisticated usage of the digits and feet while grasping objects during climbing, or grasping food. They have to be able to perform stable, efficient and often long term flexions to conduct all those movements (JUNIPER and PARR, 1998; FORSHAW and KNIGHT, 2010). Galliformes, specifically domestic chicken, belong to a group of terricolous birds known to spend most of their lives on the ground. This lifestyle does not require frequent digit movements, but these birds have an instinctive habit of spending the night in trees or other elevated places where they are most safe from predators. Therefore, permanent digit flexion is necessary in order to enable a stable grasp (SIBLEY, 2009; LOVETTE and FITZPATRICK, 2016). When comparing these two bird groups and their motor skills, it was important to note the difference in the biomechanical ratios. Parrots primarily inhabit trees where they move agilely around by grasping the branches. Galliformes spend their life on the ground, favouring walking, or running as the most important way of moving, and they are also unable to climb (SIBLEY, 2009; LOVETTE and FITZPATRICK, 2016).

Micromorphological observations. The histological characteristics of the MFDL and MFHL tendons, as well as the surrounding structures on chicken digits were in accordance with the established and described principles (QUINN and BAUMEL, 1990). The tendon itself contained not only collagen fibers but also an edge layer of cartilagefibrous elements. The chondrogenic elements described were missing or barely noticeable in parrot tendons. A potential reason for this phenomenon could be the difference in the load which the tendons endure due to the different biomechanical use. Due to the greater weight of the Galliformes, the flexor muscle tendons suffer a heavier load than in parrots and the cartilage tissue embedded in the tendon itself could act to distribute the weight of the body which the foot and the tendon carry. 
The microscopic analysis showed that the inside surface of the surrounding tendon sheath (plicae vaginae tendinis), as well as the tubercles located on the ventral surface of the tendons (area tuberculata tendinis) were clearly defined in the MFDL of the digit III in both Gallus and parrots, but differences in their morphology were clearly visible, where they are more developed in parrots. These findings are in accordance with QUINN and BAUMEL's (1990) research, which described the different shapes of the tubercles on the surface of the flexor muscle tendons which fit into the specific tendon sheath ridges. It was clear that the described differences did not influence DTLM deviations in a functional way, but represent a reflection of a specific evolutive development in different clades.

Automatism and passivity in the operation of the tendon apparatus. GALTON and SHEPHERD (2012) established on the basis of strong arguments that the long believed explanation of the function of the tendon flexor mechanism of a bird's hind limb was incorrect. Revising the explanation of this mechanism, their opinion was that passivity was unacceptable because the muscle work was necessary, and they also disputed automatic digit flexion preceded by flexion of the knee and the intertarsal joint. Namely, positioning of the body, where the centre of gravity shifted through the central pododermal pads, was essential for maintaining balance on perches whilst inactive. The birds were still able to grasp the perches after the authors inactivated separate tendons in different combinations by means of several surgeries. Even though GALTON and SHEPHERD (2012) proved that birds could maintain balance on perches in the exact same way even after DTLM deactivation, the experiments included only one species (the common starling, Sturnus vulgaris) and did not provide the possibility to project the conclusions to all Aves. Therefore, the extent to which the contraction of the muscles supports a flexed position, once established, is still questionable. However, it is certain that the described DTLM components lessen the need for muscle work by their function during the flexion, even if they do not exclude it completely.

\section{Conclusion}

DTLM is present in the hind limbs of numerous bird species and acts by increasing the function of the digits. In interaction with balancing and directing the centre of gravity of the body, durable flexion is established which is necessary during inaction as well as numerous other activities of birds. In order to establish passivity and automatism of birds' digit flexor mechanism, future research should be directed towards measuring the action potential of the working muscle group with the hind limb and foot in the flexed position during inaction.

\section{References}

AVDIĆ, A., V. ĆUTAHIJA, F. TANDIR, P. BEJDIĆ, N. HADŽIOMEROVIĆ (2014): The Anatomy of the Domestic Chicken. Veterinarski fakultet Univerziteta u Sarajevu, Sarajevo (in Bosnian). 
T. Trbojević Vukičević et al.: Morphology of the passive flexor mechanism in birds

BAUMEL, J. J., L. M. WITMER (1993): Handbook of Avian Anatomy: Nomina Anatomica Avium. Nuttall Ornthological Club, Cambridge.

BERMAN, S. L. (1984): The Hindlimb Musculature of the White-Fronted Amazon (Amazona Albifrons, Psittaciformes). The Auk, 101, 74-92.

BOCK, W. J. (1965): Experimental analysis of the avian passive perching mechanism. Am. Zool. 5,681 .

BORELLI, G. A. (1685): De Motu Animalium. Lugduni in Batavis. In: On the Movements of Animals. (Maquet P., translator, 1989). Springer Verlag, New York.

BRUSATTE, S. L., J. K. O'CONNOR, E. D. JARVIS (2015): The Origin and Diversification of Birds. Curr. Biol. 25, R888-R898.

CARRIL, J., M. C. MOSTO, M. B. J. PICASSO, C. P. TAMBUSSI (2014): Hindlimb myology of the monk arakeet (Aves, Psittaciformes). J. Morphol. 275, 732-744.

CLEMENTS, J. F., T. S. SCHULENBERG, M. J. ILIFF, D. ROBERSON, T. A. FREDERICKS, B. L. SULLIVAN, C. L. WOOD (2017): The eBird/Clements checklist of birds of the world: v2016. (Downloaded from http://www.birds.cornell.edu/clementschecklist/download/)

FEDUCCIA, A. (1996): The Origin and Evolution of Birds. Yale University Press, New Haven.

FORSHAW, J. M., F. KNIGHT (2010): Parrots of the World. Princeton University Press, Princeton, New Jersey.

GALIĆ, S. (2013): Morphological Characteristics of Birds Automatic Digital Flexor Mechanism in Species With Different Toe Allocation. Graduate Thesis, Faculty of Veterinary Medicine, University of Zagreb, Zagreb, Croatia (in Croatian).

GALTON, P., M., J. D. SHEPHERD (2012): Experimental analysis of perching in the European starling (Sturnus vulgaris: Passeriformes; Passeres), and the automatic perching mechanism of birds. J. Exp. Zool. 317, 205-215.

GOSLOW, G. E. (1972): Adaptive mechanisms of the raptor pelvic limb. The Auk 89, 47-64.

HUMMEL, G. (2000): Anatomie und Physiologie der Vögel. Verlag Eugen Ulmer, Stuttgart.

JUNIPER, T., M. PARR (1998): Parrots: A Guide to Parrots of the World. Yale University Press, New Heaven.

KAISER, G. W. (2007): The Inner Bird: Anatomy and Evolution. UBC Press, Vancouver.

KÖNIG, H. E., R. KORBEL, H. G. LIEBICH (2009): Anatomie der Vögel-Klinische Aspekte und Propädeutik. Schauttauer, Stuttgart, New York

LOVETTE, I. J., J. W. FITZPATRICK (2016): Handbook of Bird Biology $3^{\text {rd }}$ ed. (Cornell Lab of Ornithology), Wiley-Blackwell; Hoboken, New Jersey.

MAYR, G. (2008): The phylogenetic affinities of the parrot taxa Agapornis, Loriculus and Melopsittacus (Aves: Psittaciformes): hypotarsal morphology supports the results of molecular analyses. Emu 108, 23-27.

MAYR, G. (2010): Parrot interrelationships - morphology and the new molecular phylogenies. Emu 110, 348-357. 
T. Trbojević Vukičević et al.: Morphology of the passive flexor mechanism in birds

\section{DOI: 10.1071/MU10035}

McLELlAND, J. (1990): A Colour Atlas of Avian Anatomy. Wolfe Publishing Ltd., London.

NICKEL, R., A. SCHUMMER, E. SEIFERLE (1977): Lehrbuch der Anatomie der Haustiere, Anatomie der Vögel. Verlag Paul Parey, Berlin, Hamburg.

O'MALLEY, B. (2005): Clinical Anatomy and Physiology of Exotic Species: Structure and function of mammals, birds, reptiles and amphibians. Elsevier Saunders Ltd., USA.

PROCTOR, N. S., P. J. LYNCH (1993): Manual of Ornithology: Avian Structure and Function. Yale University Press, New Haven.

QUINN, T. H., J. J. BAUMEL (1983): An SEM study of a locking mechanism on avian pedal flexor tendons. Anat. Rec. 205, 156.

QUINN, T. H., J. J. BAUMEL (1990): The digital tendon locking mechanism of the avian foot (Aves). Zoomorphology 109, 281-283.

SCHAFFER, J. (1903): Über die Sperrvorrichtung an den Zehen der Vögel. Z. Wiss. Zool. Abt A. 73, 377-428.

SCHRANKE, H. (1930): Physiologisch-anatomische Studien am Fuss der Spechte. J. Ornithol. 78, 308-327.

SHEEHAN, D. C., B. B. HRAPCHAK (1980): Theory and Practice of Histotechnology. Battelle press, Columbus, Richland.

SIBLEY, C. G., J. E. AHLQUIST, B. L. MONROE (1988): A classification of the living birds of the world based on DNA-DNA hybridization studies. The Auk 105, 409-423.

SIBLEY, D. A. (2009): The Sibley Guide to Bird Life and Behavior. Alfred A. Knopf, New York.

VAN DEN BERGE, J. C., G. A. ZWEERS (1993): Myologia. In: Handbook of Avian Anatomy: Nomina Anatomica Avium, $2^{\text {nd }}$ ed. (Baumel, J. J., Ed.), Cambridge, Massachusetts: Nuttall Ornithological Club, pp. 189-250.

WATSON, M. (1869): On the mechanisms of perching in birds. J. Anat. 3, 379-384.

Received: 11 May 2017

Accepted: 13 October 2017

\section{TRBOJEVIĆ VUKIČEVIĆ, T., S. GALIĆ, D. HORVATEK TOMIĆ, S. KUŽIR: Morfološke osobitosti pasivnog fleksornog mehanizma ptica s različitim rasporedom prstiju. Vet. arhiv 88, 125-138, 2018.}

\section{SAŽETAK}

Ptice posjeduju mehanizam koji im omogućuje pasivnu fleksiju prstiju noge, a sastoji se od dvije komponente: automatskog digitalnog fleksornog mehanizma (ADFM) i digitalnog mehanizma zatvaranja tetiva (DTLM). Cilj ovoga rada bio je ustanoviti postojanje i specifičnost ovih komponenti u predstavnika ptica s anizodaktilnim (domaća kokoš) i zigodaktilnim (papige) rasporedom prstiju, primjenjujući standardnu anatomsku sekciju i histološke metode. Prostorna organizacija mišića koji imaju središnju ulogu u DTLM-u (m. flexor digitorum longus i m. flexor hallucis longus) jednaka je u papiga i domaće kokoši. Plantarni položaj četvrtog prsta, što čini razliku između anizodaktilnog i zigodaktilnog rasporeda prstiju, nije uvjetovao promjene položaja i funkcije tih fleksornih mišića. Nabori tetivnih ovojnica i kvržice na tetivama fleksornih mišića bili su 
T. Trbojević Vukičević et al.: Morphology of the passive flexor mechanism in birds

slabije razvijeni u domaće kokoši, dok su u papiga nabori i kvržice bili jasno definirani, a njihove morfološke razlike vidljive. Hondrogeni elementi nedostaju ili su jedva zamjetni u tetivama papiga. Mogući uzrok ovoj pojavi mogla bi biti razlika u opterećenju koje trpe tetive zbog različitih biomehaničkih prilika. Papige su primarno vezane za krošnje drveća gdje se vrlo spretno kreću prihvatom za grane. Kod galiformnih je ptica masa tijela znatno veća, što je posljedica prilagodbe životu na tlu, pa tetive fleksornih mišića trpe veće opterećenje nego kod papiga, dok hrskavično tkivo uklopljeno u samu tetivu može djelovati na raspodjelu mase tijela koje podnosi stopalo, pa samim tim i tetiva.

Ključne riječi: anizodaktili; zigodaktili; automatski digitalni fleksorni mehanizam; digitalni mehanizam zatvaranja tetiva; ptice 